\title{
Magnitude and Forms of Linguistic Violence against Teachers in Dar Es Salaam Schools: A Gender Comparison
}

\author{
Erasmus Akiley Msuya (Corresponding author) \\ Department of Foreign Languages and Linguistics, University of Dar es Salaam \\ Tanzania \\ E-mail: msuyaerasmus@yahoo.com
}

Received: January 21, 2016

Accepted: February 29, 2016 Published: March 28, 2016

doi:10.5296/ijssr.v4i1.8905

URL: http://dx.doi.org/10.5296/ijssr.v4i1.8905

\begin{abstract}
This study is a descriptive and interpretive account of indirect form of linguistic violence to teachers by their students in 72 males and 35 females) from assorted secondary schools in Dar es Salaam region the majority of whom were, by the time of data gathering, aged between 10 and 19 years. Data were gathered through a questionnaire and non-participatory observation. The findings indicate there the students are engaged in six forms of indirect linguistic violence, namely; sexualizing, pejorizing, stupidizing, feminizing, musculinizing, and animalizing. Further, female teachers are more victims of these forms of violence than their male counterparts at two levels: by being given comparably harsher expressions and by their body parts being referents for insults.
\end{abstract}

Keywords: Language, Linguistic Violence, Teachers, Students

\section{Introduction}

\subsection{General Introduction}

'Violence', a term referring to "nothing more than the most flagrant manifestation of power" (Arendt, 1970:35), points to the fact that violence takes many forms. In the field of philosophy, for example, according to Carver (1968), there has developed a typology of violence that includes overt and covert forms, as well as personal and institutional forms.

One form of such violence is Linguistic Violence, which is an umbrella term for the psychological and social use of any instance of language to abuse, offend, or hurt somebody 
or people. It refers to the linguistic situation whereby two people or groups asymmetrically, along the lines of power or status, in which one person or a group occupies a higher, and therefore oppressive, position in relation to the other. According to Ross (1981) sees linguistic violence as being so because "words can hurt, and one way they do so is by conveying denigrating or demeaning attitudes" (p.6). Gay (1997) likens linguistic violence to a form of verbal hatred closely associated with subordination, vulnerability and powerlessness. Again, Gay (1998) has classified linguistic violence into three broad types subtle, abusive, and grievous - in a continuum stretching from the minimally intensive to the maximally intensive. The abusive forms (which are the focus in the current study) are manifest in the conscious use of offensive expressions in "racist, sexist, heterosexist, and classist discourse" (Gay, 1998: 545). Carver's (1958) classification was personal and institutional forms of linguistic violence, depending on whether it is carried out by an individual or by an institution. For Galtung (1969) violence can be viewed from the victims perspectives to which it can be structural, if the perpetrator is an individual, or structural, characterised with power asymmetries and inequality of distribution. At the sexist level, the male folk are addressed by various neutral or "macho" terms like "men", "guys", "dudes", and "blokes" while the females are called by derogatory or demeaning names like "gals", "girls", "babes", "bitches", and "whores". Armstrong (2001), who studied and analyzed rap music, submits that this form of oppositional culture enhances what he refers to as patriarchal hegemony. Having studied a total of 490 songs, he concluded that rap artistes report and relish the abuse, rape and death of women. However, this is one sided, indicating only females as victims of linguistic violence. Dun et al (2005) explored whether people interpret the news reporting of violent acts as patriotism or terrorism. Kaplan (2011) assessed the language use by the Nazi authorities as a form of violence by the perpetrators to constructed difference, race and their perceived enemies. It particularly showed the use of the nation's press to that end but also how the Germans of Jewish ancestry received, contested and struggled for survival. More recently, Nayef and Nashar (2014), using discourse from Egyptian internet jokes, examined how language is manipulated and used to disparage women the findings showed that the 'wife' was the category most ridiculed. This is study is also one- sided, indicating only females as victims of linguistic violence.

Oluga et al (2015) studied the paradoxical existence between the quest for global peace as worded in the national anthems and the linguistic violence of some of the countries' national anthems. They noted that some countries national anthems rationalise or encourage using arms, shedding blood, going to war and paying supreme sacrifice.

Generally, what most scholars agree on is that linguistic violence is actually a form of violence as it hurts the victims even if it is not accompanied to, or followed by, physical, and overt forms of violence.

In Africa most studies on linguistic violence are predominantly in West Africa, notably Nigeria. For example, Fakoya (2007) studied contextual and conversational relevance of Yoruba-sexually grounded proverbs exploring sexist language in unfair portrayal of Nigerian women in English medium newspapers; Tsaair (2009) studied strategic and ideological use of naming to stereotype and oppress women in Tiv oral narrative while Yusuf (1994) dealt with 
gender bias and cumulative misogyny in English and Yoruba proverbs. A further study by Salami (2004) dealt with women (affected psychologically by subtle linguistic violence), irrespective of their levels of education, defined themselves largely as 'wives of' and registered to their husbands as 'Oko ri ni' to mean 'master' or 'superior'. In South Africa, Burton and Leoschuts (2012) report female teachers being given abusive labels as contrasted to their male colleagues and River (2001) studied forms of verbal harassment to minority sexual groups of gays, lesbians and bisexuals.

Few scholars have focused on violence against men, an example here being a research conducted at University of Nebraska by Xia and Bosch (2006) on teen dating violence found that both rural and urban females tended to be as verbally aggressive as males.

\subsection{The Problem}

In the realm of education, many studies have been on violence against students and students by their teachers, in which, completely counter to current initiatives that combat school-based violence, have shown that some teachers assume the verbal perpetrator role by engaging in harmful and sometimes violent behaviours towards students. The first study in this area is by Brendgen et al (2006) who examined the course and stability of verbal abuse by the teacher from kindergarten up to grade 4 and the link between verbal abuse by the teacher and children's behavioral, emotional, and academic adjustment and noted that verbal abuse by the teacher seemed to be a highly stable phenomenon for at-risk children whilst the children who were relatively well adjusted were at low risk of becoming the target of verbal abuse by the teacher. The second study was by Sharpe (2012) on the extent of teacher abuse of elementary students, the characteristics of teachers who abuse, the types of abusive behaviors teachers engage in, the reasons for teacher abuse, and the impact on victims and witnesses. The study revealed that verbal and emotional abuse was most often reported though physical and sexual abuses were also indicated. Third, Krugman and Krugman (1984) outlined what they considered abusive behaviours by educators which included, inter alia, excessive screaming and rants that resulted in students crying; making publicly degrading comments toward students; labelling the students as stupid or ineffectual, and threatening students (verbally and via body language). A fourth study was by Briggs and Hawkins (1996) who focused on spurning, spurning, a method teachers use to control children or punish certain behaviours by the use of verbal and nonverbal acts that reject or degrade the children. In this particular study, instances of spurning by teachers included: screaming at or demeaning children, making belittling personal comments directed towards children; rejecting the child or their work; verbally abusing, and harassing and berating a child until they cry.

Another form of linguistic violence in educational institutions, according to Afful (2007), is that of nick-naming. In a study by Liao (2006), it was found that there was a high frequency of nicknaming practices among male students. In a Graduation Memory Album of Feng Dong Junior High School, it was reported that 119 out of $152(78.29 \%)$ female students had nicknames while 131 of 142 (91.61\%) male students had nicknames. The study disclosed that only three out of eight classes in which all of the students, either female or male, had nicknames. In the rest of the classes, more males had nicknames than the females. Also in the 
US, Kiesling (1997) study on verbal practices in an American College Fraternity showed that joking and insults were commonly used by male students more than their female counterparts to reinforce heterosexuality. Also Kuranchie (2012) made a descriptive study of senior high school students' nicknaming by their peers of their teachers in the Brong Ahafo region of Ghana. He found that there was high prevalence $(77.2 \%)$ of the nicknaming phenomenon in the senior high schools with boys spearheading was partly due to lack of attention paid to it by educational authorities. It was also revealed that negative nicknames had some psychological effects on the bearers which consequently discouraged them from active participation in class.

However, a few studies have been conducted in the area of linguistic violence against teachers. For example, Lipsett (2009) in the US found that more than a third (39\%) of teachers had been confronted by an aggressive parent or guardian. Johnson (2008) investigated the dynamics of bullying behaviors of parents towards teachers in the workplace-the school. The study involved 130 teachers from a Mid-Atlantic State in suburban Excellence High School. The teachers were provided with a survey questionnaire to investigate the extent to which confrontational parents try to bully teachers. The findings indicated a statistical significance between physical assault and male teachers. Also the teachers were more likely to be verbally abused by parents who try to confront teachers.

Triggers that caused confrontation that indicted statistical significance were, a) student removal of a student from a sports team, b) had homework issues, c) showed low grades on a report card, d) low scores on a test, and e) low attendance rates. Further, the ASTI survey (1999) revealed that teachers had experienced bullying by parents whereby sixty-eight percent of respondents stated they had experienced verbal abuse, 50\% stated they had been deliberately excluded by another person at school, and $26 \%$ reported that they had been the target of personally offensive graffiti, abusive work related telephone calls or malicious damage to their property. In yet another study by the Ontario English Catholic Teachers Association survey (2006), it was reported that Canadian educators witnessed a parent verbally abusing a teacher $36 \%$ of the time, up from $29 \%$. In the same survey, $23 \%$ of educators report they have witnessed a parent physically assaulting and intimidating a teacher, up 14\% from 2001. Another study in this area was Jaksec's (2005) assessment of the frequency at which educators experience parental aggression where he found that $60 \%$ experienced profanity or shouting directed at them by parents on at least two occasions during the school year. $70 \%$ experienced false accusations levelled against them by parents during the school year, while $79 \%$ experienced three or more occasions reported receiving parental threats to contact other authorities regarding their situation. A recent study in this area was by Ek et al (2013) which examined the narratives of bilingual Latina teacher candidates in South Texas. The findings revealed that the bilingual teacher candidates are linguistically subordinated by the marginalized status of Spanish in the United States and by the deficit perspectives of Spanish of the South East.

In Africa we have few of such studies. One was in Zimbabwe by Research and Advocacy Unit [RAU] (2012) made on various forms of violence that teachers experience from the government the results of which showed that teachers were yelled at, physically harassed or 
given humiliating remarks mostly during school hours and sometimes, in full view of school children. Also, in a study by PLAN (2008:13) in sub-Saharan Africa, it was noted that female teachers often resort to emotional abuse and insulting language to control learners' behavior as an alternative to corporal punishment.

All these studies point to the fact that linguistic violence is found virtually in all realms of life and that in education teachers are both victims and perpetrators of linguistic violence though at varying degrees of magnitude. However, the studies on linguistic violence against teachers have focused mainly on parents, administrators and political elites leaving out students/students as perpetrators. This may be due the studies focusing on direct verbal confrontation to teachers, which is a phenomenon not prevalent in education since teachers have more institutional and professional powers over their students than vice versa.

\subsection{Aim of the Study}

This study focuses on indirect form of linguistic violence to teachers by their students in Tanzania, with a gender comparison perspective. Specifically, the study sought to find out:

a) Whether and to what extent the students have been involved in badmouthing their teachers.

b) Different forms of verbal attacks against teachers by their students.

\section{Participants and Methods}

\subsection{Participants}

A total of 107 students from assorted secondary schools in Dar es Salaam region were employed in the study the majority of whom (45, which is $42 \%$ ) were, by the time of data gathering aged between 10 and 19 years, which is the age during which the majority of the youths are at school going age given the fact that the age of starting Grade 1 is 7, which means the majority of these would be between Form one and five. Another group consisted of those aged between 20 and 29 years who were 38 (which is $35.5 \%$ ), which, again point to the fact that these respondents are attending their high school studies. The 18 (17\%) who indicated their being above 18 years were those who were attending secondary education as independent candidates.

As for their sex, the majority were females as they accounted for $66 \%$ of all 107 respondents while the $35(33 \%)$ were males. Only a negligible percentage (1\%) did not indicate their sex. Having women as the majority in this study was particularly important in ensuring whether and to what extent females are not only victims but also aggressors in linguistic violence, and this is in addition to ascertaining the extent to which linguistic violence may have negatively impacted women's psycho-social realms of life by the virtue of taking some gender-discriminating forms of linguistic aggressions as commonsensical and unquestionable.

The respondents' education background was such that most (86, which is $80.4 \%$ ) of the respondents were attending public secondary schools as contrasted with $18(16.8 \%)$ who were in private schools and only $3(2.8 \%)$ did not indicate their schooling. The fact that over 
$80 \%$ were in public schools had a positive source triangulation in terms of character diversity of the learners since public schools would usually have a single admission criteria of admission namely, passing grade seven national examination as contrasted to private schools who might have additional institutional specific, charisma based criteria for admission into their schools. However, the inclusion of private secondary schools was a strategy for us to capture the extent of indiscriminate widespread of linguistic violence against women.

\subsection{Data-gathering Instruments}

Two data gathering instruments were used in this study. The first was a questionnaire, which was administered to all respondents. It consisted of both closed-in and open-ended items seeking the respondents' use of different forms of indirect linguistic violence to their teachers or their witnessing it being used by someone else. The second one was observation, during which the researcher and his assistants were aloof observers to different informal gatherings in which some conversations were being carried out regarding an incident in or outside the classroom that involved a teacher and one of his/her students/students or a group of students or any kind of gossip about a teacher's conduct or behaviour which there might be a chance of some evaluative labels being used.

\section{Findings}

The findings are organised into two themes. The first is indirect violence, or badmouthing of teachers, followed by various forms of indirect linguistic violence, namely; sexualizing, pejorizing, stupidizing, musculining, and animalizing.

\subsection{Badmouthing a Teacher}

In a questionnaire, the respondents were asked if they had ever been involved, at least once, in a gossip with a friend or a colleague about their teachers irrespective of what the reasons were. Their responses are summarized in Figure 1 below.

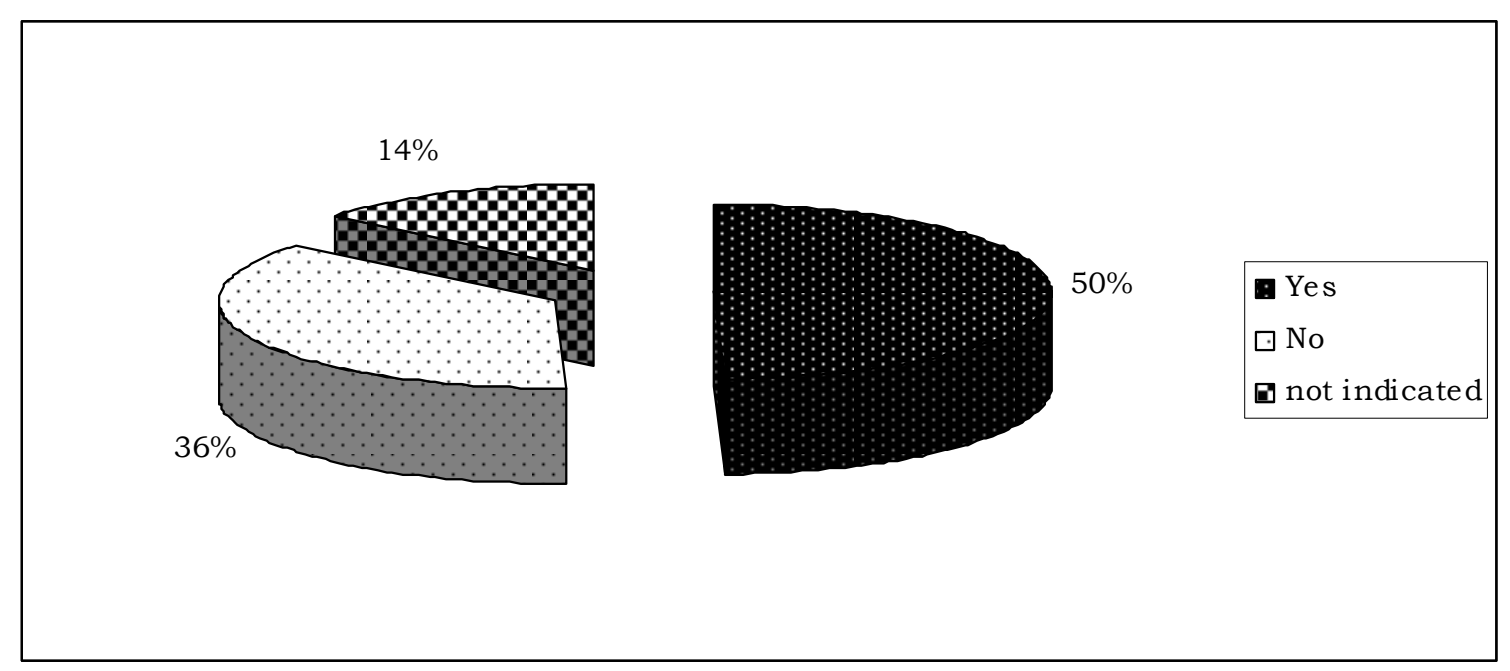

Figure 1. Students' Involvement in Linguistically Attacking their Teachers 


\section{Ml Macrothink}

Data in Figure 1 above are highly telling of the extent to which young people (boys and girls) at secondary school level engage in indirect linguistic violence against their teachers: This is evidenced by a half of the respondents indicating that they had been involved in badmouthing their teachers, while 36\% denied involvement in such linguistic behaviour. When asked if they had ever gossiped against people other than their teachers (their peers, their parents or care-takers/guardian or their neighbours), $70 \%$ said yes while $25 \%$ denied such involvement while the remaining $5 \%$ chose not to indicate anything.

In a follow up question, the respondents were further asked the extent to which they had also badmouthed other people, in addition to the teachers; their comparative responses are summarized in 2 below.

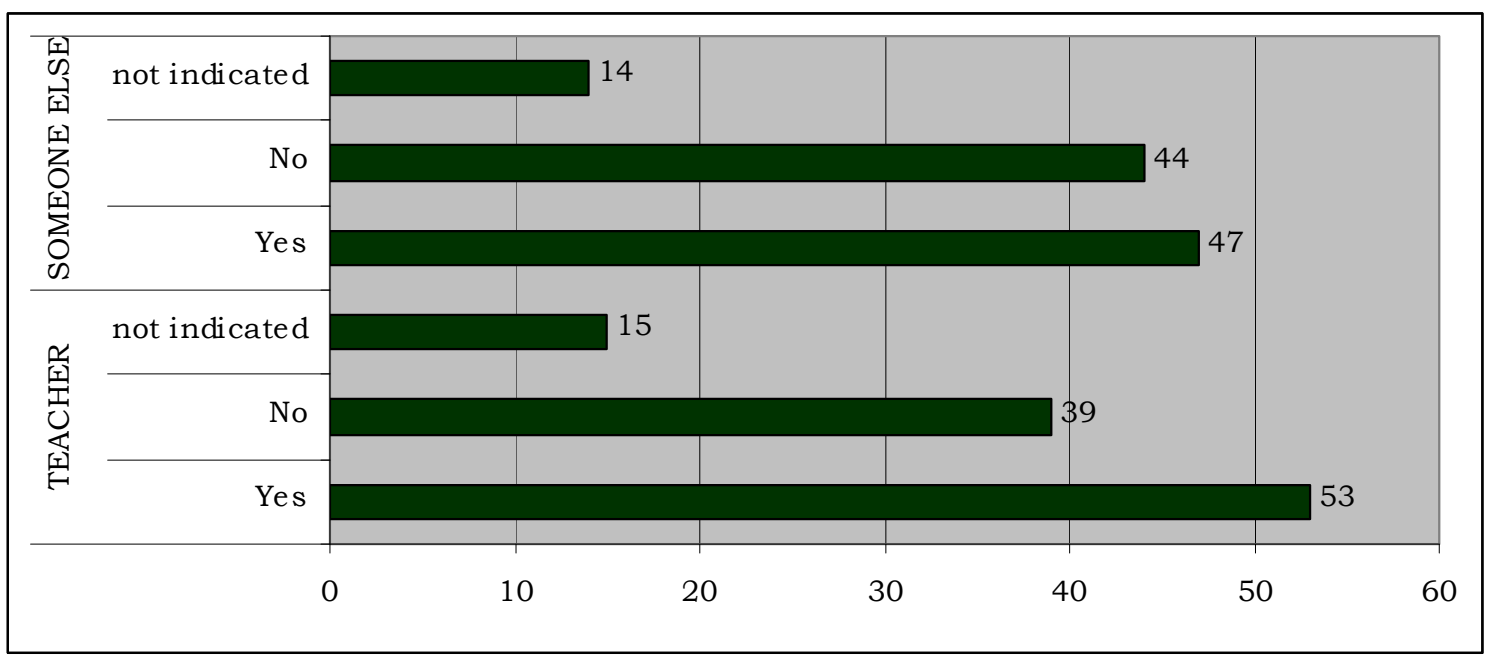

Figure 2. Comparative Extent of Gossiping against Teachers and Other People

The data in Figure 2 above show that teachers are more preferred targets of indirect linguistic violence than other people, as evidenced by $53 \%$ vs $47 \%$ of respondents who indicated to have been involved in gossiping about others. This is contracted with $39 \%$ and $44 \%$ who reported not to have been involved in such activity against teachers and others, respectively. Two things stand out in these data: first, there is no significant difference (only $6 \%$ ) between those who admitted to have badmouthed their teachers and those who badmouthed other people. This points to the fact that gossiping as a form of linguistic violence that involves human emotion (anger, disillusionment, desperation) cannot be strictly confined to either the actors on the students' formal educators (the teachers) and the others (who are largely fellow students and other non-teaching staff members). Human interaction, linguistic or otherwise, is spontaneous and does not obey strict formal boundaries between formal and non formal environments.

Secondly, the predominance (in terms of frequency) of teachers as victims of linguistic violence is due to their role as formative and regulating agents in the educative arena. Since most of the students' prime time is spent in the school environment within which teachers are 
an integral part, and since more teacher-student engagement is via language medium, it is more likely that such teachers may be their students linguistic target in either commending their work or (or the context of this study criticizing or condemning them.

\subsection{Forms of Verbal Attacks to Teachers}

Having indicated that they were involved in indirect verbal attacks to their teachers, the respondents were then asked to try to remember the words, phrases or sentences they used. From the list they provided and their respective recurring frequencies we grouped such phrases or sentences into five thematic categories which we labelled sexualizing, pejorizing, stupidizing, musculinizing, and animalizing. Each of the categories is presented and discussed as follows:

\subsubsection{Animalizing}

This was a strategy in which a person uses the phrases/terms containing words that reduce their victim, or compares them, to an animal or a thing mainly through employment of similes or metaphors. Figure 3 below summarizes expressions and differing magnitudes of such form of linguistic violence.

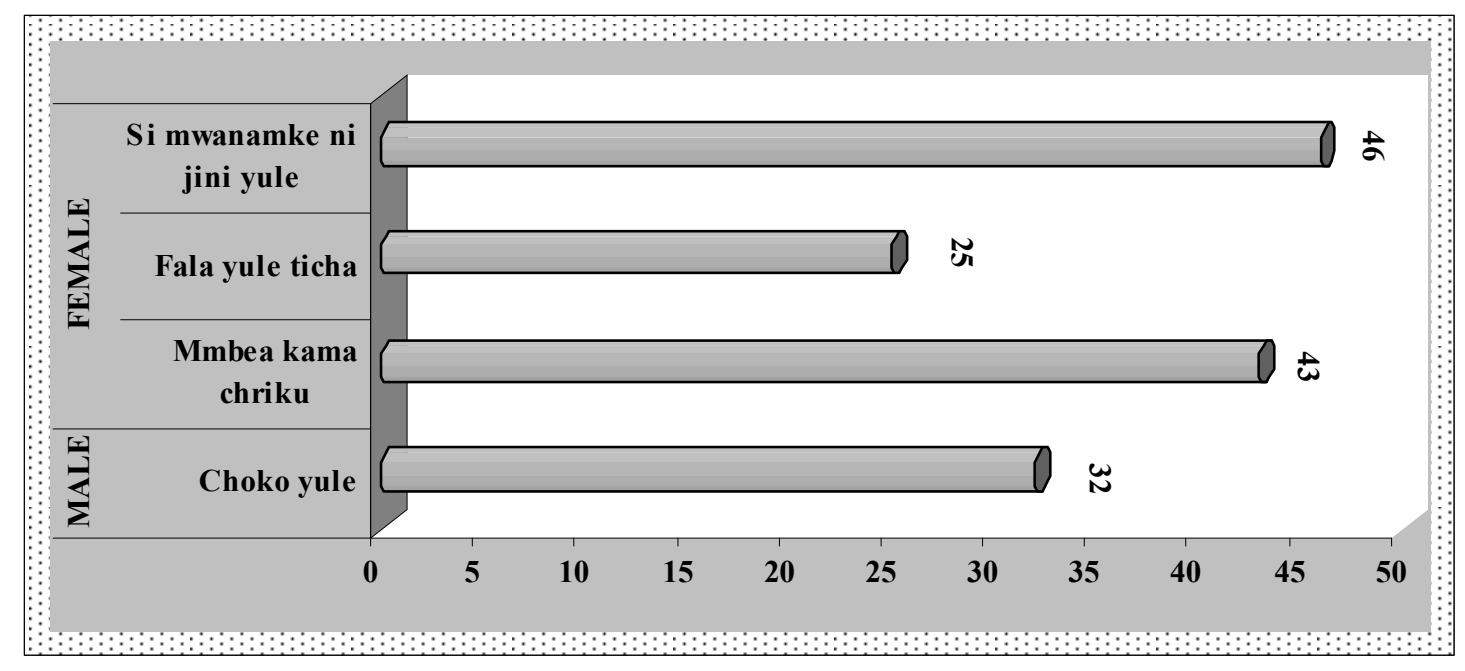

Figure 3. Animalizing Teachers

The data in figure 3 above show that female teachers are more quantitatively and qualitatively victims of animalizing form of indirect linguistic violence than their male counterparts. At quantitative level, female teachers had three examples of such animalization as contrasted to the male's only one instance.

At qualitative level one sees more variability in women than in men in the likening things or animals to which the victims are made to resemble. A male teacher is only likened to a "choko" (i.e. 'a street dog') whereas a female teacher is likened to (a) a parrot (in 'mbea kama chiriku') by $43 \%$ of respondents' referring to their (female teachers) gossiping behavior; (b) imbecile (in 'fala yule ticha') by virtue of $25 \%$ of the respondents' perceived imbecility 
(for reasons not probed in this study), and (c) a ghost in 'Jini tu Yule' and 'si mwanamke ni jini' showing that the teacher's behaviour is not only counter norm for human beings but also contrary to what is expected of a human being.

Related to comparative variability in male and female teachers is the notion of severity of insult the animalizing language serves. The male teacher being likened to "choko", a term pointing to their being like a street dog is far less severe to imbecility and devilizing (in the use of ghost) which were used as referring terms against female teachers. Moreover, female teachers' being given animalizing terms point to the fact that their students perceive them as behaving counter to their day to day professional ethical conduct as teachers.

Therefore, in animalizing form of linguistic violence female teachers were more victimized than male teachers.

\subsubsection{Feminizing}

Feminizing is a term referring to the verbal aggressor's use of either women attributes or linguistic aggression labels meant for women, but used for the teachers of the opposite sex as shown in Table 1 below.

Table 1. Linguistic Feminizing against Teachers

\begin{tabular}{|c|c|c|c|c|}
\hline$s / n$ & Male Victim & Frq & Female Victim & Frq \\
\hline 1 & Anachonga kama mwanamke (he is a gossiper like a woman) & 42 & Anajishaua (a pretender) & 23 \\
\hline 2 & Yule avishwe kanga (let him be adorned with waist beads) & 19 & & \\
\hline 3 & Dume jike lile (that one a female in male physique) & 46 & & \\
\hline 4 & Anajishaua tu (a pretender) & 44 & & \\
\hline 5 & mbea kama jike (a news monger, like a woman) & 41 & & \\
\hline 6 & mwanamme jina (a man just by name) & 49 & & \\
\hline
\end{tabular}

Feminizing, unlike animalizing, makes the male teachers suffer more victimization than their female counterparts both quantitatively and qualitatively.

As the data in Table 1 above illustrate, at quantitative levels the males had 6 forms of feminizing (and understandably explainable by their biological inclination) as contrasted to their female counterparts, who had only one. Even at the level of frequency of use, item 2 (Yule avishwe shanga) with 19 frequencies the other five forms of feminizing are far more in use (between 41-49 frequencies) than the single form against female teachers (with 23 frequencies).

At qualitative level, male teachers' labels of feminizing were apparently very severe by virtue of their being likened to female in terms of perceived behaviour; for example, in the first instance, the phrase "anachonga kama mwanamke" (i.e. "He talks a lot like a woman") to which 42 respondents indicated to have used. In using such terms to a male teacher, one sees 
that the respondents, most of whom were women, show a belief that women talk far more than men. The same goes for items "mbea kama jike". In the second, "Yule avishwe shanga" ("let that one be adorned with waist cowrie's shells") the respondents likened the male teacher to a woman in his perceived sexual orientation. This is because some women in Africa have a preference for adornment include strings of courier shells around their waist, partly for self-expression of beauty as women and partly their readiness for sexual provision of optimal erotic pleasure to their male sexual partners. In that sense the male teacher is sexually classified as behavioring like a woman. Related to this form of feminizing are item 3, where the phrase Dume Jike translates as 'a man who is a female", which was shared by 46 respondents, and item 6, where the phrase Mwanamme jina which translates as "a male just by name" i.e. his behaviour (linguistic, aesthetic etc) is similar to women's only that he is physiologically a man. In all these, a man is linguistically feminized. While those terms are a form of violence to male teachers by the virtue of sexual transgression (and thus offensive to a male gender), yet the real subtle violence is seeing a woman as a source of social/psychological anomaly to which a man is likened to. This 'otherness' approach puts men as being unlike women and a man is an 'other' if he behaves similar to women's 'notioned' list of behaviour, be it linguistic or otherwise.

Even the 'anajishaua' which, translates as "one behaves contrary to what she really desires", is among the notional list of women, only that is it is for women who are no 'of class and elegance'. So, a woman who behaves like that, even though that behaviour is classified as women's, is badmouthed as not being refined and elegant in manners. In other words, ironically, a woman who is biologically feminine is sarcastically 'further feminized', and this is regarded as a form of linguistic violence.

\subsubsection{Musculinizing}

Masculining, in the context of this study, essentially attributes a male linguistic behaviour or non-elegance (or lack of beauty) to someone who is (usually) a female. This form of indirect linguistic violence was not quite popular for teachers since there was only "sura kama dume" (i.e. "(her) appearance is like a man's") as the only masculinizing instance against female teachers. This form of violence was shared by 48 respondents, $30(63 \%)$ of whom were female, and the remaining $18(37 \%)$ male students. This form of musculinizing a female teacher, notably in the area of aesthetics, is deemed offensive to any lady since female physique is related to softness and appealing to the eyes (of males) while a male physique is related to acrobatic, body building masculine behaviour, coarseness and machoness. Just like in feminizing, one notes yet a subtly deeper form of violence where females are made to reject their natural physique by virtue of meeting the expectations of the eyes that ought to be attracted (usually male's eyes) while at the same time there is no musculinizing of a male teacher implying whatever is masculine is, to a male, desirable.

\subsubsection{Pejorizing}

This was an umbrella term for phrases or sentences that were meant to make the victim feel or look unimportant, unattractive and useless. Table 2 below summarizes such phrases/sentences and their varying frequencies. 
Table 2. Pejorizing Terms against Teachers

\begin{tabular}{|c|c|c|c|c|}
\hline sn & Male Victim & Frq & Female Victim & Frq \\
\hline 1 & $\begin{array}{l}\text { Atasutwa yule (he will be jilted, that } \\
\text { one) }\end{array}$ & 15 & $\begin{array}{l}\text { Dawa yake ipo jikoni (the herbs are } \\
\text { boiling for her) }\end{array}$ & 8 \\
\hline 2 & $\begin{array}{l}\text { Hanifanyi kitu (he can do nothing to } \\
\text { me) }\end{array}$ & 43 & mnoko sana (she is mean) & 46 \\
\hline 3 & $\begin{array}{l}\text { ukikutana nae usiku mpige jiwe (Stone } \\
\text { him, if you meet him by night) }\end{array}$ & 11 & $\begin{array}{l}\text { ana nguo chache (she has few } \\
\text { clothes) }\end{array}$ & 43 \\
\hline 4 & Mnoko (he is) staunch and mean) & 38 & $\begin{array}{l}\text { Anajichubua (she a applies heavy } \\
\text { cosmetis on herself) }\end{array}$ & 32 \\
\hline 5 & Mnafiki (he is) a hypocrite) & 22 & Mweusii (she is so black) & 31 \\
\hline 6 & Bwege (he is) an imbecile) & 33 & $\begin{array}{l}\text { hana hata gari (she doesn't even have } \\
\text { a car) }\end{array}$ & 8 \\
\hline 7 & Lambalamba ((he is) a candy) & 23 & $\begin{array}{l}\text { anapenda sana starehe (she a party } \\
\text { monger) }\end{array}$ & 10 \\
\hline 8 & Mmbea (he is) a gossiper) & 21 & Hapendezi (she is unattractive) & 31 \\
\hline 9 & Mchonganishi (he is) a disharmonic) & 27 & $\begin{array}{l}\text { anaiba waume wa watu (she steals } \\
\text { others'husbands) }\end{array}$ & 22 \\
\hline 10 & hana huruma (he is) merciless) & 11 & $\begin{array}{l}\text { hajui kuvaa (she does not know how } \\
\text { to dress herself) }\end{array}$ & 42 \\
\hline 11 & Anajisikia (he is) showy) & 15 & Hana shepu (she is shapeless) & 33 \\
\hline 12 & $\begin{array}{l}\text { ana simu ya tochi (he has handset with } \\
\text { a torch) }\end{array}$ & 16 & $\begin{array}{l}\text { akivaa wigi anakuwa kituko } \\
\text { (whenever she puts on a wig she } \\
\text { looks like a zombie) }\end{array}$ & 21 \\
\hline 13 & $\begin{array}{l}\text { ana hasira muda wote ((he) always } \\
\text { bitter) }\end{array}$ & 8 & Anashushua (a pretender) & 10 \\
\hline 14 & yupoyupo tu ((he is) without direction) & 30 & ana misifa (very showy) & 16 \\
\hline 15 & $\begin{array}{l}\text { anapenda kujichekesha (he likes } \\
\text { giggling) }\end{array}$ & 20 & $\begin{array}{l}\text { anapenda kuchapa (she like canning } \\
\text { students) }\end{array}$ & 13 \\
\hline 16 & $\begin{array}{l}\text { anapendelea kufauatilia sana } \\
\text { wanafunzi (he enjoys bothering } \\
\text { students) }\end{array}$ & 32 & Kiherehere (she is a limelighter) & 25 \\
\hline 17 & ana upendeleo (he is a desriminator) & 21 & yule ni nuksi (she is bad omen) & 27 \\
\hline 18 & $\begin{array}{l}\text { yupo shalo sana (he is very } \\
\text { shallow-minded) }\end{array}$ & 31 & Mchochezi (a disharmonic) & 34 \\
\hline 19 & ana roho mbaya (he is bad-hearted) & 24 & $\begin{array}{l}\text { ana nyodo (she likes to look } \\
\text { important) }\end{array}$ & 37 \\
\hline 20 & $\begin{array}{l}\text { anajifanya handisam (he pretends to } \\
\text { be handsome) }\end{array}$ & 23 & $\begin{array}{l}\text { hana sura nzuri (she is not } \\
\text { good-looking) }\end{array}$ & 48 \\
\hline 21 & & & $\begin{array}{l}\text { Anaringa (she sees herself more } \\
\text { important than others) }\end{array}$ & 41 \\
\hline 22 & & & $\begin{array}{l}\text { anajiona keki wakati hana lolote (she } \\
\text { likes herself to a cake but she is a } \\
\text { nobody) }\end{array}$ & 30 \\
\hline 23 & & & $\begin{array}{l}\text { mwizi wa wanaume (she is a men } \\
\text { stealer) }\end{array}$ & 31 \\
\hline
\end{tabular}

This form of linguistic violence, as shown in Table 2 above, was far the most popular and 
most diverse, with male teacher having 20 and the female 23 items.

For male teachers, most of their perjorating words are to do with their social/professional incapacitation or waywardness. Examples, are items 2 (hanifayi kitu, i.e."he can do nothing to me") by 43 respondents; item ' $m n o k o$ ', i.e. an over strict person, by 38 respondents; Items 9 and 10 both pointing to scandal monger and a social disharmonic, respectively. Other related terms are mercilessness (item 10), showiness (item 11) segregationist (item 17) unkindness (item (19) and nosiness (item 20); A few point to the victim's perceived emotional anomaly e.g. Item 13 (always angry'), and item 14 (he is a giggler). A few other also point to dispossession e.g. item 12 ('he has a low cost cellular phone') or lack of direction; e.g. item 14 (He has no sense of direction). Two other items point to the victims' professional misconduct; these are item 15 , pointing to the perceived favoritism to students and item 16 , on shallowness of his teaching.

Female perjorizing items, on the other hand, are more related to their externalities and social conduct. Example of attacks an external physique are item 3 on her skin whitening with 31 respondents), item 4 on her being 'black' (to mean blackness is ugliness) which leads to skin bleaching which is yet a form of pejorizing. It seems a case of hopelessness that one is insulted for being black and when she eventually resorts to skin bleaching she is also attacked. Item 19 is also an attack to a lady for a lack of body beauty (shared by 48 respondents, 30\% of whom were ladies).

There were also some items that were related to what ladies do to make themselves attractive. Such are items as 8, (she is unattractive") with 31 respondents, item 10 that "she does not know how to dress up' (with 42 respondents), and item 12 ('if she puts on a wig she looks like a caricature'), with 21 respondents. Some other items are rather grievous as they are attacks on moral conduct of the victims; examples are item 9 ('she steals other peoples husbands' (by 22 respondents) and item 22 (“" she is a thief of other ladies' male lovers'), both items showing that the female teachers in question are morally low when it comes to marital or sexual relations. A few are the teachers' attacks on their not owning some utilities or if they have some, they are insufficient, e.g. not having enough clothes (item 3) and not having a car (item 6). Like their male counterparts, some pejorizing terms are related to their professional conduct; e.g. (item 15 (that 'she enjoys beating students'), item 14 (that 'she likes being praised/recognized' and item 2 (that 'she is over strict').

\subsubsection{Sexualizing}

These terms are related to the woman's sexual and reproductive organs and related processes, their excretory organs and/ or their processes or acts related to sexual intercourse. All these aimed at making the victim feel less than normal and 'straying the norms' of handling sexuality, overdoing it or her depravity of the same (Note 1).

Sexualizing, ranking second after perjorizing in popularity among the youths, involves focalizing a person's sexual behavior/relationship by stating that she/he is involved (or has been a victim of) counter-social or counter-norm sexual activity, on the one hand, and likening them to their sexual organs or those of the opposite sex, on the other. Just like in 
animalizing and feminizing forms of violence, women teachers suffered more violence than their male counterparts. This was both quantitatively (by having bigger (16) number of sexualizing than the male teachers who had 11) and qualitatively (by having more variability and the severity of the terms used).

For male teachers, theirs was mainly an attack on their alleged homosexuality where phrases like shoga and msenge, both referring to being a homosexual, which predominated the respondents' frequency. The verbal phrases referring to the act of practicing homosexuality are wanambonyeza a slang referring to homosexuality. Two items likened the male teachers to their backsides, while another item is more offensive as the male teacher was likened to a female's sexual organ. One other item was the very opposite of the other terms since, by calling a male person hanithi, the linguistic aggressors refer to their victim's sexual dysfunction.

As for female teachers, most terms point to the teachers' alleged forced sexual relations (straight or otherwise) and labels referring to their moral looseness of character as well as their non involvement sexually for lack of male partners. Items related to forced sexual relations (which ought to have invoked sympathy) include 'she was raped' and that she was forced into homosexual relations. One items referred to female teachers as 'visitors sleeping mat (a common mockery for loose women who make love to any man indiscriminately). One other item likened female teachers to their sexual and execratory organs. One peculiar item labelled the teachers 'Kigoli' (which translates as 'a virgin girl') to which someone would perceive it as a compliment but in the context of hostile verbal attacks, direct or indirect, it refers to the victim's lack of a male sexual partner.

Generally, women teachers' level of victimization is not only on their being more targets of the badmouthing than the male teachers, but also by their sexual organs being used as referring expressions for male teachers' linguistic harassment.

\subsubsection{Stupidizing}

Stupidizing, a more particularized form of pejoritivizing, involves words or phrases from the verbal aggressors aimed at making a victim feel or look ignorant or imbecile. Figure 4 below summarizes the respondents' use of stupidizing terms with their respective frequencies of occurrence. 


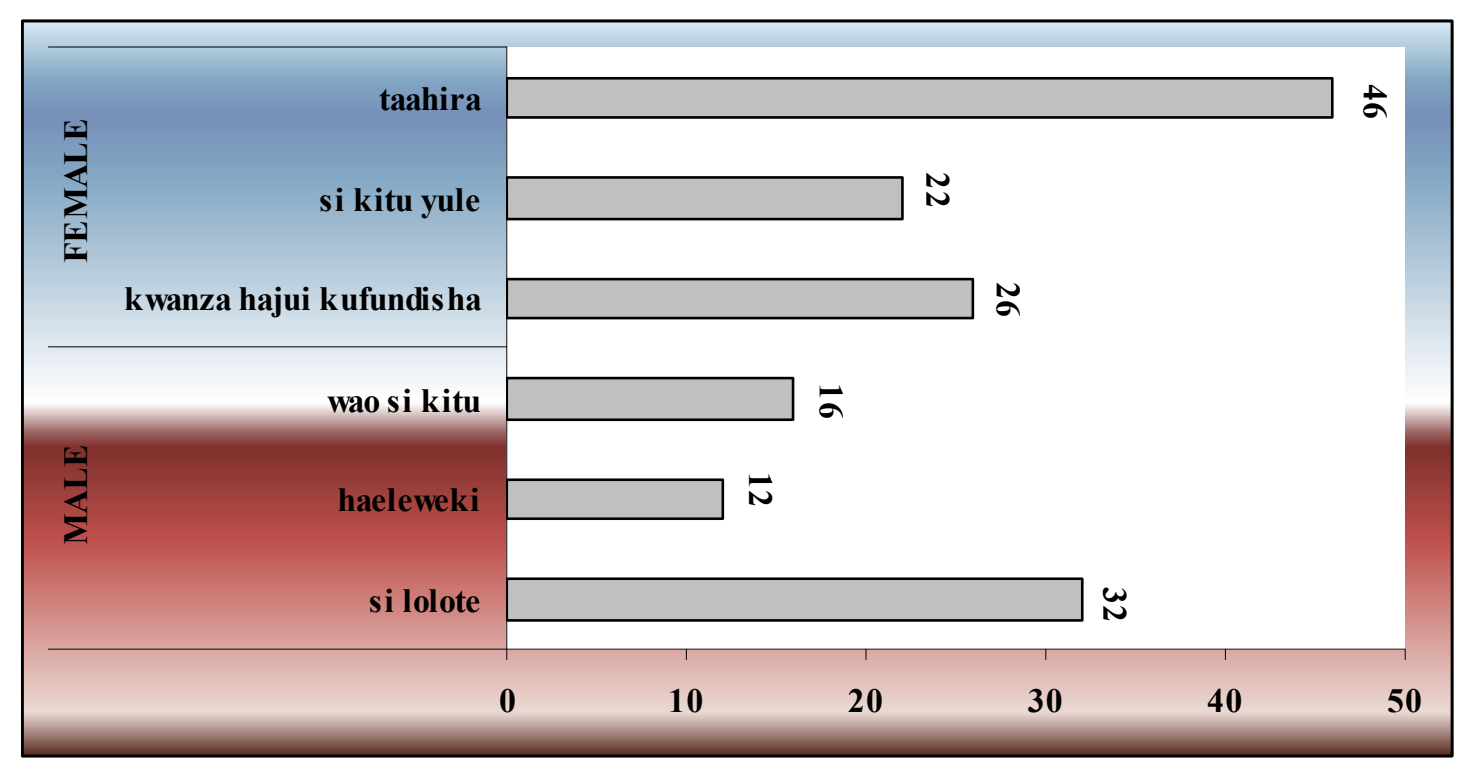

Figure 4. Instances of Linguistic Stupidizing

Figure 4 above shows that this form of linguistic violence was quantitatively equal in both male and female teachers, even though there are more frequencies of occurrence for female teacher victims.

For male teachers, the phrase 'si lolote' ('he is a nobody') is more a less similar to the female's 'si kitu yule' (she is nothing') with the difference that a male is made to feel non existent from the world of the learned and influential where a woman is made to be complete absence, i.e. not counting in physical existence and in socio-interactive engagement. Also the male's 'haleweki' ("it is impossible to understand him") is more or less similar to kwanza hajui kufundisha' ("first, she doesn't know how to teach") but for the former there are some elements of knowing how to communicate (in classroom situation or elsewhere) only that the verbal attackers (who are these teachers' students) claim not to understand him. The latter, however, points to an evaluative dismissal of the female teachers' ability to teach. A more violent form of language against female teachers is in the use of "taahira" (a mentally retarded person). This is beyond stupidizing as it signifies that the female teacher's mental state is subnormal and is thus not worth working as a teacher and that she is a social misfit.

In short, in stupidizing also, the female teachers' verbal attacks are harsher and more damaging than the male teachers.

\section{Conclusion}

The current study has shown that both male and female teachers have shown that both male and female teachers have suffered from their students' indirect verbal attacks. The findings have also shown that female teachers are more victims of this form of violence than their male counterparts at two levels: by being given comparably harsher expressions and by their body parts being referents for insults. 
Another observation in this study is the fact that all forms of linguistic violence are indirect. This is because of the unequal power relations between the students, who are in this study linguistic violence perpetrators, and their teachers, who are linguistic violence victims. Given the powerlessness of the perpetrators, the only way available to them to vent their dissatisfaction and anger is through gossiping and badmouthing their teachers. The situation would certainly be the opposite if the teachers were the perpetrators of such forms of violence to their students.

Third, most of the expressions used by the respondents are not unique to educational or school contexts. Most of these are expressions acquired by hearing them being used by other members of the speech communities to which they belong. This calls for sensitivity in language use in the presence of youngsters.

\section{References}

ABS (Australian Bureau of Statistics). (2005). Recorded Crime Victims 2005. Retrieved October 20, 2013, from www.abs.gov.au

Afful, J. B. A. (2007). Address Terms and Variation among University Students in Ghana. Nordic Journal of African Studies, 16(2), 179-196.

Akindele, F. (1991). And how shall I address you: A study of Teknonym as an Aspect of Linguistic Etiquette in Yoruba. In F. A. Soyoye \& L. O. Adewole (eds.), In Honour of Professor Ayo Bamgbose (pp. 38-47). Ile-Ife: Obafemi Awolowo University Press.

Arendt, H. (1970). On Violence. New York: Harcourt, Brace and World, Inc.

Armstrong, E. C. (2001). Gangsta Misogyny: A Content Analysis of the Portrayals of Violence against Women in Rap Music, Journal of Criminal Justice and Popular Culture, $8(2), 96-126$.

Associated Secondary Teachers of Ireland (ASTI) (2005). Bullying at Work. Dublin: AST.

Boulton, M. J. (1997). Teachers' views on Bullying: Definitions, Attitudes and Ability to Cope. British Journal of Educational Psychology, 67, 223-233. http://dx.doi.org/10.1111/j.2044-8279.1997.tb01239.x

Brendgen, M., Wanner, B., \& Vitaro, F. (2006). Verbal Abuse by the Teacher and Child Adjustment from Kindergarten through Grade 6. Pediatrics, 117(5), 1585-98. http://dx.doi.org/10.1542/peds.2005-2050

Briggs, F., \& Hawkins, R. M. F. (1996). Child Protection: A Guide for Teachers and Child care Professionals. Family Matters, 47, 56-63.

Burges, D. L. (1973). The Racist Use of the English Language. The Black Scholar (pp. 4-21).

Burton, P., \& Leoschut, L., (2012). School Violence in South Africa, Results of the 2012 National School Violence Study, Centre for Justice and Crime Prevention, Monograph series, No 12, Cape Town, March 2013. 


\section{Macrothink}

International Journal of Social Science Research

ISSN 2327-5510

2016, Vol. 4, No. 1

Cameron, D. (1996). The Language-gender Interface: Challenging Co-optation. In V. Bergvall, J. Bing, \& A. Freed (Eds.), Rethinking Language and Gender Research: Theory and practice (pp. 31-53). London: Macmillan.

Cameron, D. (1998). Gender, Language and Discourse: A review Essay. Signs, 23(4), 945-973. http://dx.doi.org/10.1086/495297

Carlson, M. (2007). Images and values in textbook and practice: Language courses for immigrants in Sweden. In M. Carlson, et al. (eds.), Education in Multicultural Societies Turkish and Swedish perspectives. Istanbul: Swedish Research Institute in Istanbul (pp. 125-142).

Carver, N. (1968). What Violence is. The Nation 209 (June 24) (pp. 817-822).

Craig, W. M., Henderson, K., \& Murphy, J. G. (2000). Prospective Teachers' Attitudes towards Bullying and Victimisation. School Psychology International, 21, 5-21. http://dx.doi.org/10.1177/0143034300211001

Crawford, M. (1995). Talking Difference: On Gender and Language. London: Thousand Oaks.

Ek, L. D., Sanchez, P., \& Cerecer, P. D. Q. (2013). Linguistic Violence, Insecurity, and Work: Language Ideologies of Latina/o Bilingual Teacher Candidates in Texas. International Multilingual Research Journal, 7, 197-219. http://dx.doi.org/10.1080/19313152.2013.768144

Fakoya, A. (2007). Sexually Grounded Proverbs and Discourse Relevance: Insights from Yoruba language. In M. Olateju, R. Taiwo \& A. Fakoya (eds.), Towards the Understanding of Discourse Strategies (pp. 192-215). Agolwoye: Olabisi Onabanjo University Press.

Fishman, P. (1990). Conversational Insecurity. In D. Cameron (Eds.), The Feminist Critique of Language: A Reader (pp. 234-250). New York: Routledge.

Galtung, J. (1969). Violence, Peace and Peace Research. Journal of Peace Research, 6(3), 167-191. http://dx.doi.org/10.1177/002234336900600301

Garver, N. (1958). What Violence Is. The Nation 209 (June 24, 1968).

Gay, N. C. (1997). The Reality of Linguistic Violence against Women. In L. O'Toole, and J. Schiffman, (Eds.), Gender Violence: Interdisciplinary Perspectives. New York: New York University Press (pp. 467-473). http://dx.doi.org/10.1080/10402659808426201

Gay, N. C., (1998). The Practice of Linguistic Nonviolence. Peace Review, 10(4), 545-547.

Goodard, A., \& Patterson, L. M. (2000). Language and Gender. London: Longman.

Gottman, J. M. (1994). What Predicts Divorce? The Relationship between Marital Processes and Marital Outcomes. Hillsdale, NJ: Erlbaum.

Graddol, D. \& Swann, J. (1989). Gender Voices. Oxford: Blackwell.

Holmes, J. (1995). Women, Men, and Politeness. London: Longman. 


\section{Macrothink}

International Journal of Social Science Research

ISSN 2327-5510

2016, Vol. 4, No. 1

UN Office on Drugs and Crime, International Crime Victims Survey. (2000). Retrieved October 20, 2013, from www.icpsr.umich.edu/icpsrweb/ICPSR/studies/3803

Irigaray, L. (1989). “The Gesture in Psychoanalysis.” In T. Brennan (Ed.), Between Feminism and Psychoanalysis. London: Routledge.

Jaksec, C. (2005). The Difficult Parent. Thousand Oaks, California: Corwin Press.

Johnson, J. E. (2008). Do Parents try to Bully Teachers through Confrontation? Unpublished Doctoral Dissertation the Virginia Polytechnic Institute and State University.

Kaplan, T. P. (2011). The Language of Nazi Genocide Linguistic Violence in the Struggle of Germans of Jewish Ancestry. Analyses of Social Issues and Public Policy, 5(1), 67-86.

Kiesling, S. F. (1997). Power and the Language of Men. In S. Johnson and U.H. Meinhof (eds.), Language and Masculinity, Oxford: Blackwell.

Krugman, R. D., \& Krugman, M. K. (1984). Emotional Abuse in the Classroom. The Pediatrician's Role in the Diagnosis and Treatment. American Journal of Diseases of Children, 138, 284-286. http://dx.doi.org/10.1001/archpedi.1984.02140410062019

Kuranchie, A. (2012). Students' Nicknames: Their sources and Effects on Learning. Journal of Education and Practice, 3(14), 126-132.

Lakoff, R. (1975). Language and a Woman's Place, New York: Harper.

Liao, C. (2006). Linguistic Analysis of Nicknames of Junior High School Students. National University of Kaohsiung, Taiwan.

Lipsett, A. (2009). Abuse of Teachers by Parents The Guardian, Monday 6 April 2009. Retrieved September 20, 2014, from www.theguardian.com

Litosseliti, L. (2006). Gender and Language: Theory and Practice. London: Hodder Education.

McEachern, A., Alude, O., \& Kenny, M. (2008). Emotional Abuse in the Classroom: Implications and Interventions for Counsellors. Journal of Counselling and Development, 32(2), 165-177. http://dx.doi.org/10.1002/j.1556-6678.2008.tb00619.x

McEvoy, A. (2005). Teachers who Bully Students: Patterns and Policy Implications. Paper Presented at the Hamilton Fish Institute's Persistently Ontario Safe Schools Conference, Philadelphia, USA.

McGhee, P. E. (1979). Humour: Origins and Development. San Francisco: Freeman.

Menesini, E., Fonzi, A., \& Smith, P. K. (2002). Attribution of Meanings to Terms related to Bullying: A Comparison between Teacher's and Pupil's perspectives in Italy. European Journal of Psychology of Education, 17, 393-406. http://dx.doi.org/10.1007/BF03173593

Msibi, T. (2013). Homophobic Language and Linguistic Resistance in KwaZulu-Natal, South Africa. In Atanga, L .L., Sobonile, E. E., Litosseliti, L. \& J. Sunderland (eds). Gender and 
Language in Sub-Saharan Africa: Tradition, Struggle and Change (pp. 253-274). http://dx.doi.org/10.1075/impact.33.17msi

Murray, S. O. (1979). The Art of Gay Insulting, Anthropological Linguistics, 21(5), 211-223.

Nayef, H., \& El-Nashar, M. (2014). Dissecting the Poisoned Honey. Sexist Humour in Egypt: A Linguistic Analysis of Sexism in Colloquial Cairene Arabic Jokes. Analis. Quaderns de Comunicacio i Cultura, 50, 131-146.

Nesbit, W. C., \& Philpott, D. F. (2002). Confronting Subtle Emotional Abuse in Classrooms. Guidance and Counselling, 17:32-38.

Olasunkanmi, O., Seng, T. C., \& Rajoo, G. S. R. (2015). The Paradox of the Quest for Global Peace and the Linguistic Violence of Some Countries National Anthems: A Critical Discourse Perspective. Global Journal of Human-Social Science, 15(1) (online).

Omenugha, K. A. (2007). Playing Unfair: The Synergy of Culture and Sexism in Nigerian News Discourse. In R. Taiwo, A. Odebunmi, and A. Adetunji (eds.), Perspectives on media discourse (pp.156-181). Munich: Lincom Europa.

Ontario English Catholic Teachers Association. (2006). Joint Briefing Addressing Workplace Bullying in Ontario.

Research and Advocacy Unit [RAU]. (2012). Political Violence and Intimidation against Teachers in Zimbabwe. Report prepared for the Progressive Teachers Union of Zimbabwe (PTUZ) by the Research and Advocacy Unit [RAU].

River, I. (2006). Bullying and Homophobia in UK schools: A Perspective on Factors Affecting Resilience and Recovery. Journal of Gay and Lesbian Issues in Education, 3(4), 11-43. http://dx.doi.org/10.1300/J367v03n04_03

Ross, S. (1981). How Words Hurt: Attitude, Metaphor, and Oppression. In V. Mary (ed.), Sexist Language: A Modern Philosophical Analysis: Littlefield: Adams and Co., p. 195.

Rudd, P. W. (2004). Weapons of Mass Destruction: The Unshared Referents of Bush's Rhetoric. Pragmatics, 14(4), 499-525. http://dx.doi.org/10.1075/prag.14.4.05rud

Russell, D. (2002). Self-deprecatory Humour and the Female Comic: Self-destruction or Comedic Construction? Third Space, 2(1), 34-39.

Salami, L. O. (2004). Deference and Subordination. Gender Roles and Other Variables in Addressing and Referring to Husbands by Yoruba Women. Linguistik online, 21(4), 65-80.

Salisbury, J., \& Jackson, D. (1996). Challenging Macho Values. London: Farmer Press.

Sharpe, G. W. B. (2011). Behind the Closed Door: Exploring Teacher Bullying and Abuse of Students, Characteristics of the Teacher, and Impact. Unpublished Doctor of Education thesis Department of Sociology and Equity Studies, Ontario Institute for Studies in Education of the University of Toronto.

Spender, D. (1980). Man made Language. London: Routledge. 
Tannen, D. (1991). You Just don't Understand: Women and Men in Conversation. London: Virago.

Thomas, L., \& Wareing, S. (1999). Language, Society and Power: An Introduction. London:Routledge

Tsaair, J. T. (2009). Gender Politics, Ideology and Naming Strategies in Tiv Oral Narratives. In A. Odebunmi, A. E. Arua, * S. Arimi (Eds.), Language, Gender and Politics, Lagos: Concept Publication (pp. 85-101).

Twemlow, S. W. (2004). Preventing Violence in Schools. Psychiatric Times, 21(4), 61-67.

Twemlow, S. W., Fonagy, P., Sacco, F., \& Brethour, J. R. (2006). Teachers who Bully Students: A Hidden Trauma. International Journal of Social Psychiatry, 52(3), 187-198. http://dx.doi.org/10.1177/0020764006067234

Wareing, S. (1999). Language and Gender. In L. Thomas \& S. Wareing (eds.), Language, Society and Power: An Introduction (pp. 65-82). London: Routledge. http://dx.doi.org/10.4324/9780203426968_chapter_5

Xia, C.C., Bosch, Y. R., Todd, M., \& Garrett, A. (2006). A Youth Perspective on Adolescent Dating Violence: A Qualitative Study. Peer reviewed poster presented at the National Council for Family Relations Conference, Minneapolis, MN.

Yusuf, Y. K. (1994). From 'motherless babies' to 'Babiless Mothers': A Sexist Metaphorical Transition of Female Undergraduates. Women and Language, 17 (2), 30-32.

Yusuf, Y. K. (2002). Sexism, English \& Yoruba. Linguistik Online, 11(2), 23-48.

\section{Notes}

Note 1 . We need to emphasize here that the respondents, given their being under age, were not asked to produce words or phrases of the sexual nature. They were only asked to produce, as much as they can remember, the actual words they used in badmouthing their teachers. That some of the utterances were of sexualizing nature was our own classification.

\section{Copyright Disclaimer}

Copyright for this article is retained by the author(s), with first publication rights granted to the journal.

This is an open-access article distributed under the terms and conditions of the Creative Commons Attribution license (http://creativecommons.org/licenses/by/3.0/). 